\title{
Disaccharidase Levels in Iron Deficient Rats at Birth and during the Nursing and Postweaning Periods: Response to Iron Treatment
}

\author{
PHILIP LANZKOWSKY, ${ }^{(17)}$ GUNGOR KARAYALCIN, AND FREDERICK MILLER \\ Departments of Pediatrics and Pathology, School of Medicine, Health Sciences Center, State University of New York \\ at Stony Brook and Division of Pediatric Hematology-Oncology, Department of Pediatrics, Long Island Jewish- \\ Hillside Medical Center, New Hyde Park, New York, USA
}

\begin{abstract}
Summary
Newborn rats born to iron deficient mothers (IDM) were found to have significantly lower hemoglobin, sucrase, lactase and maltase levels compared to control newborn rats.

Rats born to IDM and nursed by IDM, when sacrificed at 21 days of age, had statistically significantly lower hemoglobin, serum iron, sucrase, lactase and maltase levels compared to control rats. Rats born to IDM, but nursed by iron sufficient mothers (ISM) and sacrificed at 21 days of age, had hemoglobin, serum iron and sucrase levels compared to control rats whereas lactase and maltase were not corrected by 21 days of nursing by ISM. Rats born to IDM and nursed by either IDM or ISM for 21 days were given intramuscular iron dextran and placed on iron sufficient diet (ISD) for 7 days. These animals experienced correction of the hemoglobin, serum iron, sucrase and maltase levels compared to control rats, whereas intestinal lactase was not corrected by 7 days of ISD and intramuscular iron.

Rats born to ISM, nursed by IDM and sacrificed on day 21 had significantly lower hemoglobin, serum iron and intestinal lactase levels compared to control rats. Rats born to ISM and nursed by IDM were given intramuscular iron dextran on day 21 and placed on an ISD from day 21-28. These animals had a return in hemoglobin, serum iron, sucrase and maltase levels comparable to control rats.

Rats born to and nursed by ISM and maintained on an iron deficient diet from day 21-84 had significantly lower hemoglobin, serum iron, sucrase, lactase and maltase levels compared to control rats. Rats born to and nursed by ISM, maintained on iron deficient diet from day 21-84, and then given intramuscular iron dextran on day 84 and maintained on an ISD until day 92, experienced correction of the hemoglobin, serum iron and lactase levels compared to control rats. Intramuscular iron and 7 days of ISD did not correct the sucrase and maltase levels in these rats. Lactose tolerance tests in iron deficient rats showed flat curves compared to controls. After iron treatment, lactose tolerance curves returned to control values.

Iron deficiency in rats in utero, during the nursing and postweaning period causes, in addition to anemia, a reduction in jejunal disaccharidase activity because of an alteration in the enzymes of the brush border membrane. Varying degrees of reduction and response of certain disaccharidases to iron treatment are dependent on the time of iron deprivation in relationship to the intrauterine and postnatal development of the digestive and absorptive functions in the small intestine.

Alterations in the levels of disaccharidases demonstrated in this paper represent another aspect of the spectrum of biochemical effects of iron deficiency.
\end{abstract}

\section{Speculation}

Iron deficiency has a profound effect on protein synthesis. Alterations in the levels of disaccharidases represent only a fraction of this effect.
The temporary reduction in lactase and other disaccharidases in iron deficient infants might predispose them to malabsorption and diarrhea, which contribute to the lowered serum protein and increased incidence of low weight percentiles observed in iron deficient infants.

Many studies in animals and man have shown that during iron deficiency there are various biochemical changes demonstrable in most tissues and organs of the body. Some of these alterations appear to be permanent and others reversible. The purpose of this investigation was to study the effect of iron deficiency on disaccharidase levels in the intestine of rats at birth and on rats during the nursing and postweaning periods and to determine whether alterations in disaccharidase activity induced by iron deficiency are reversible with iron therapy.

\section{MATERIALS AND METHODS}

Animals. Sixty adult female Sprague-Dawley rats weighing from 225-249 g were studied. Thirty rats, comprising the experimental group, were placed on a specially prepared iron-depleted diet (IDD). The diet was prepared by General Biochemical Laboratories, Chagrin Falls, $\mathrm{OH}$. The remaining 30 adult female rats, the control group, were given the same diet but iron (ferrous ammonium citrate $250 \mathrm{mg}$ /liter) was added to their drinking water (iron sufficient diet-ISD). Three wk later, all female rats from both groups were mated and their pups studied. When administered parenterally to the pups, iron was given as iron dextran, $5 \mathrm{mg}$ intramuscularly (IM).

Collection of specimens. Blood specimens for blood glucose determinations and hematologic studies were obtained from the tail veins. Preweaning rats were fasted for $2-4 \mathrm{~h}$ and postweaning rats for $10-16 \mathrm{~h}$ before sacrifice. At the time of sacrifice, rats were anesthetized with ether and exsanguinated by cannulating the abdominal aorta. Blood was taken for serum iron determination and hematologic studies. In younger rats a $2.5 \mathrm{~cm}$ segment of jejunum, measured distally from the ligament of Treitz, was removed and in older rats a $5.0 \mathrm{~cm}$ segment of jejunum was removed. Each segment was rinsed in ice-cold saline.

Preparation of intestinal tissue. Because of the small size of the animals at birth, brush border membrane isolation was not possible and homogenates of the whole thickness of the jejunum were prepared as described by Seetharam et al. (13). In newborn animals, five groups consisting of ten pooled intestines were employed for each point whereas in older suckling and adult rats, single preparations were measured. Centrifuged homogenates were lyophilized and stored at $-70^{\circ} \mathrm{C}$ until the conclusion of the experiment to assure identical assay conditions.

Assay of disaccharidases. The fluorimetric technique developed by Peters et al. (10) was employed for disaccharidase assays. The homogenate was dissolved in $0.5 \mathrm{ml}$ of $0.05 \mathrm{M}$, pH 8.8 Tris-glycine $\mathrm{HCl}$ and $0.10 \mathrm{ml}$ of a suitable dilution was added to $0.10 \mathrm{ml}$ of the appropriate substrate $(0.056 \mathrm{M}$ disaccharide in $0.1 \mathrm{M}$ sodium 
maleate buffer at $\mathrm{pH}$ 6.0) at timed intervals. The homogenate buffer was diluted $1: 15$ and sometimes even higher dilutions were necessary. The inhibitory effect of Tris was not significant under the assay conditions employed. Incubation was carried out at $37^{\circ} \mathrm{C}$ for $60 \mathrm{~min}$ and then a mixture of glucose oxidase, horseradish peroxidase and homovanillic acid in $\mathrm{pH} 8.0$ Tris- $\mathrm{HCl}$ buffer was added for an additional $30 \mathrm{~min}$ of incubation. The reaction was stopped by the addition of $\mathrm{pH} 10.6$ borate buffer. The vanillin formed was assayed spectrophotometrically on a Turner photofluorimeter using $315 \mathrm{~nm}$ as the exciting wavelength and $425 \mathrm{~nm}$ as the fluorescing wavelength. All studies were performed at least in duplicate and the data is expressed as the mean of the measured values. Activity is given in $\mathrm{U} / \mathrm{g}$ protein.

Assay of protein content. The protein content was determined using the Lowry procedure with bovine serum albumin as the reference standard (8).

SDS-Polyacrylamide electrophoresis. Modification of the method of Freiburghaus et al. (2) was employed. One to four $\mathrm{mg}$ of protein was applied to $0.9 \mathrm{~cm}$ acrylamide gels after dissolving the material in sodium dodecyl sulfate (SDS), $0.11 \%$. In initial runs the solution was boiled for $10 \mathrm{~min}$ and compared to those in which it was maintained at $4^{\circ} \mathrm{C}$ before application. There was far greater preservation of enzyme activity without heat treatment and no difference in protein staining. For this reason samples were handled as described by Seetharam et al. (13). Runs were performed at $3^{\circ} \mathrm{C}$ using 2 mamps/gel until the bromphenol blue dye front reached the bottom of the gel, about $5 \mathrm{~h}$. Gels were divided and half of them immediately frozen at $-20^{\circ} \mathrm{C}$. Gels used for scanning were fixed in a solution of $25 \%$ isopropanol $(\mathrm{v} / \mathrm{v})$ and $10 \%$ acetic acid $(\mathrm{v} / \mathrm{v})$ for a minimum of $2 \mathrm{~h}$. Staining was carried out overnight in Coomassie blue $(0.25 \%)$, $50 \%$ methanol, and $10 \%$ acetic acid. Destaining was accomplished with $10 \%$ acetic acid-5\% methanol on a rotary shaker. Gels were scanned at 550 nm using a Gilford Model 2400-S automatic recording spectrophotometer equipped with a gel scanning accessory.

In newborn pups separation of the mucosal brush border from the remaining tissue was not possible because of the small size. Homogenates, therefore, consisted of submucosal and muscularis layers in addition to the mucosal brush border. Of necessity, this lead to additional peaks of protein compared to scans of homogenates consisting only of mucosal brush border. The patterns however from these newborn pups were completely reproducible.

Scanning gels for enzymatic activity. Frozen gels were sliced into $1 \mathrm{~mm}$ discs and eluted with $1.10 \mathrm{ml}$ water, overnight, at $4^{\circ} \mathrm{C}$. Samples were then assayed according to the colorimetric procedure of Freiburghaus et al. (2) or the fluorimetric method of Peters et al. (10).

Lactose tolerance test. Lactose tolerance test was performed by administering lactose in a dose of $1 \mathrm{mg} / \mathrm{g}$ of body weight as a $10 \%$ solution through a feeding tube into the stomachs of the rats. Blood glucose levels were determined by a micromethod ( 9 ) from the blood specimens obtained by tail vein puncture at $0,15,30,45$ and $60 \mathrm{~min}$ intervals.

Analysis of data. All dta were analyzed using Student's $t$ test, two-tailed, with $2 P<0.10$ being significant (equivalent to $P<$ $0.05)$

\section{RESULTS}

The iron deficient rats, although seemingly healthy, were severely anemic. At the time of delivery mother rats fed on IDD had a significantly lower hemoglobin and serum iron levels $(9.22$ $\pm 1.3 \mathrm{~g} / \mathrm{dl}$ and $71.4 \pm 4.2 \mu \mathrm{g} / \mathrm{dl}$ respectively) compared to mother rats fed on ISD $(13.42 \pm 0.57 \mathrm{~g} / \mathrm{dl}$ and $101.8 \pm 4.3 \mu \mathrm{g} / \mathrm{dl})(2 P<$ $0.001)$.

Study I: Effect of maternal iron deficiency on the hemoglobin and disaccharidase levels in rats at birth. In order to compare the effect of maternal iron deprivation on the disaccharidase levels at birth, 50 pups from iron deficient mothers (IDM) were randomly selected and compared to a comparable group from the iron sufficient mothers (ISM). The data is shown in Table 1. Animals born to IDM have lower hemoglobin, sucrase, lactase and maltase levels.
Table 1. Hemoglobin and jejunal disaccharidase levels in newborn rats born to iron deficient and control rats

\begin{tabular}{llcccc}
\hline \multicolumn{1}{c}{ Group } & & $\begin{array}{c}\text { Hgb } \\
(\mathrm{g} / \mathrm{dl})\end{array}$ & $\begin{array}{c}\text { Sucrase } \\
(\mathrm{U} / \mathrm{g})\end{array}$ & $\begin{array}{c}\text { Lactase } \\
(\mathrm{U} / \mathrm{g})\end{array}$ & $\begin{array}{c}\text { Maltase } \\
(\mathrm{U} / \mathrm{g})\end{array}$ \\
\hline Iron deficient & Mean & 4.72 & 0.01 & 2.02 & 0.01 \\
& S.D. & \pm 0.37 & \pm 0.00 & \pm 1.72 & 0.00 \\
Control & Mean & 10.3 & 0.42 & 4.02 & 0.92 \\
& S.D. & \pm 0.57 & \pm 0.47 & \pm 1.16 & \pm 0.47 \\
& $2 P$ & $<0.001$ & $\mathrm{NS}^{2}$ & $<0.1$ & $<0.02$ \\
\hline
\end{tabular}

$\mathrm{NS}=2 P>0.1$.

In order to investigate whether the effect of iron was confined to disaccharidases (among the intestinal proteins) and to determine if iron deficiency produced only quantitative changes SDS-gel electrophoresis was carried out with parallel enzyme assays on each molecular weight range. Figure 1 (as compared to the control homogenate in Fig. 2) reveals two important observations. First, there is a dramatic shift of protein $\left(\mathrm{OD}_{550}\right.$ material) from higher molecular weight species on the left to smaller moieties on the right. This suggests a reduction in the ability to synthesize large molecules compared to normal (Fig. 2). It is important to note that it required three times as much protein from the iron deficient animals to obtain comparable enzyme levels. Second, the enzymes from the iron deficient animals are distributed in several peaks, at least three slurred fractions for each enzyme. In the controls (inset in Fig. 2) there is one maltase, two lactase and three sharp sucrase peaks; a pattern much closer to what is found in the intact adult (one maltase peak of high molecular weight; two sucrase peaks, one under the maltase and one of substantially smaller mass; and a lactase peak between the two sucrase activities are usually noted in brush border preparations). We interpret this consistent reproducible difference as reflecting a disturbance in enzyme synthesis beyond a simple diminution in synthetic rate.

Study II: Effect of maternal iron deficiency and iron deficiency during nursing period on hemoglobin, serum iron and jejunal disaccharidase levels in rats 21 days of age and the effect of iron administration. In order to examine the effect of maternal iron deficiency and iron deficiency during the nursing period, four groups of five animals each were established using newborn pups born to IDM. Of a control group of 10 rats born to and nursed by ISM, five were sacrificed at 21 days and five were sacrificed at 28 days of age. Group I consisted of animals nursed by their own IDM and sacrificed at 21 days. Group II was animals nursed by ISM and sacrificed at 21 days. Group III was animals nursed by their own IDM and on day 21 the animals were given IM iron and the animals were maintained on and ISD until sacrificed on day 28. Group IV was animals nursed by ISM and on day 21 given IM iron and the animals were maintained on an ISD until sacrificed on day 28.

The results of this experiment are shown in Table 2. Rats born to and nursed by IDM and sacrificed on day 21 had a profound reduction in hemoglobin, serum iron, sucrase, lactase and maltase levels compared to the control group. Rats born to IDM and nursed by ISM for a period of 21 days were able to correct the hemoglobin, serum iron and sucrase levels compared to control rats. This indicates that there was enough iron in the milk of ISM to reverse these findings within a period of 21 days. The lactase and maltase levels were not corrected during this period of time.

Rats born to and nursed by IDM for 21 days, when placed on an ISD and given intramuscular iron dextran on day 21 , showed an increase in hemoglobin, serum iron, sucrase and maltase levels. This indicates correction of these deficiencies, which were induced by iron deficiency, during the fetal and nursing period by a 7 day treatment of ISD and intramuscular iron. The lactase deficiency was not corrected in a group of rats born to IDM but nursed by ISM.

Study III: Effect of iron deficiency during the nursing period on the hemoglobin, serum iron and disaccharidase levels in rats 21 days of age born to iron sufficient mothers and the effect of iron therapy. Seven pups born to ISM were nursed by IDM and maintained on 


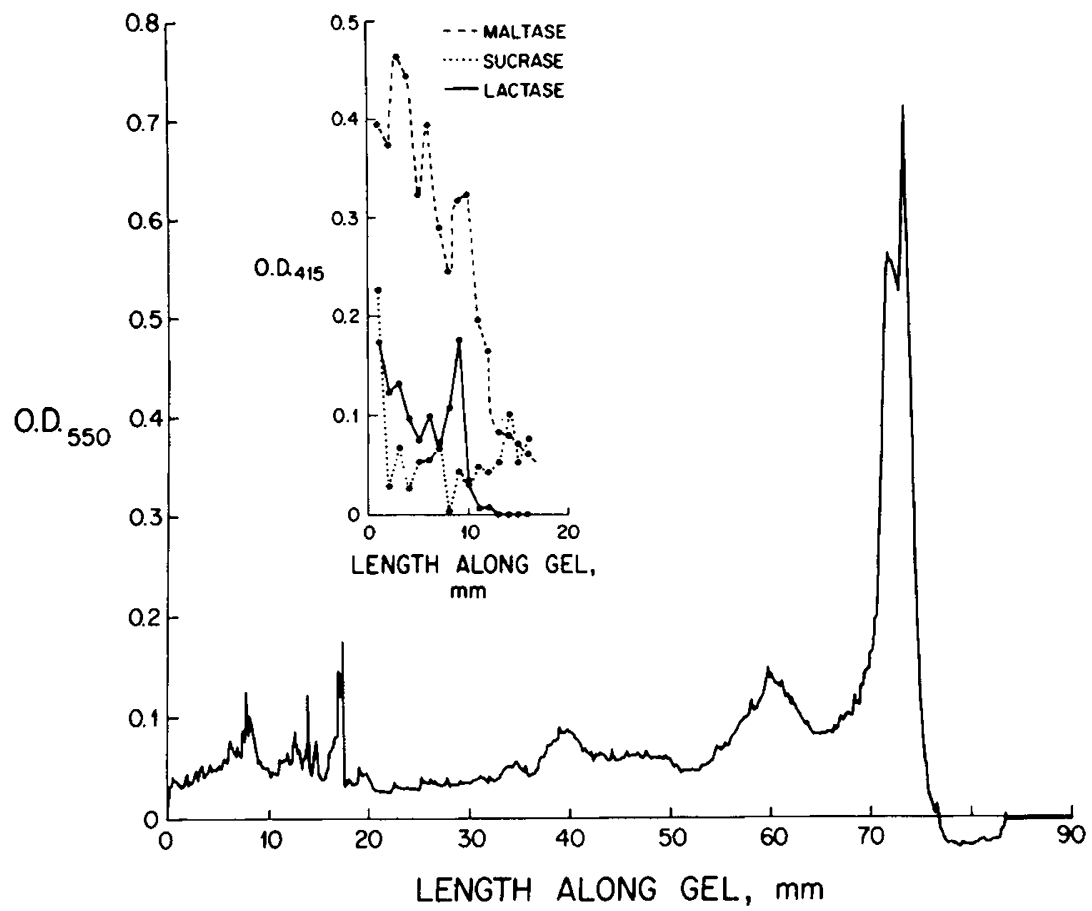

Fig. 1. Gel scans of intestinal homogenates run on SDS-polyacrylamide disc gels with corresponding enzymatic activities of eluates from gel slices shown on inset graphs. Composite of 10 newborn pups born to IDM. The enzyme activities do not reflect the total present in the homogenates (lactase was far greater than maltase which in turn was considerably more than sucrase, Table 1) but indicate the location and distribution of the enzymes. Protein load, $3.0 \mathrm{mg}$.

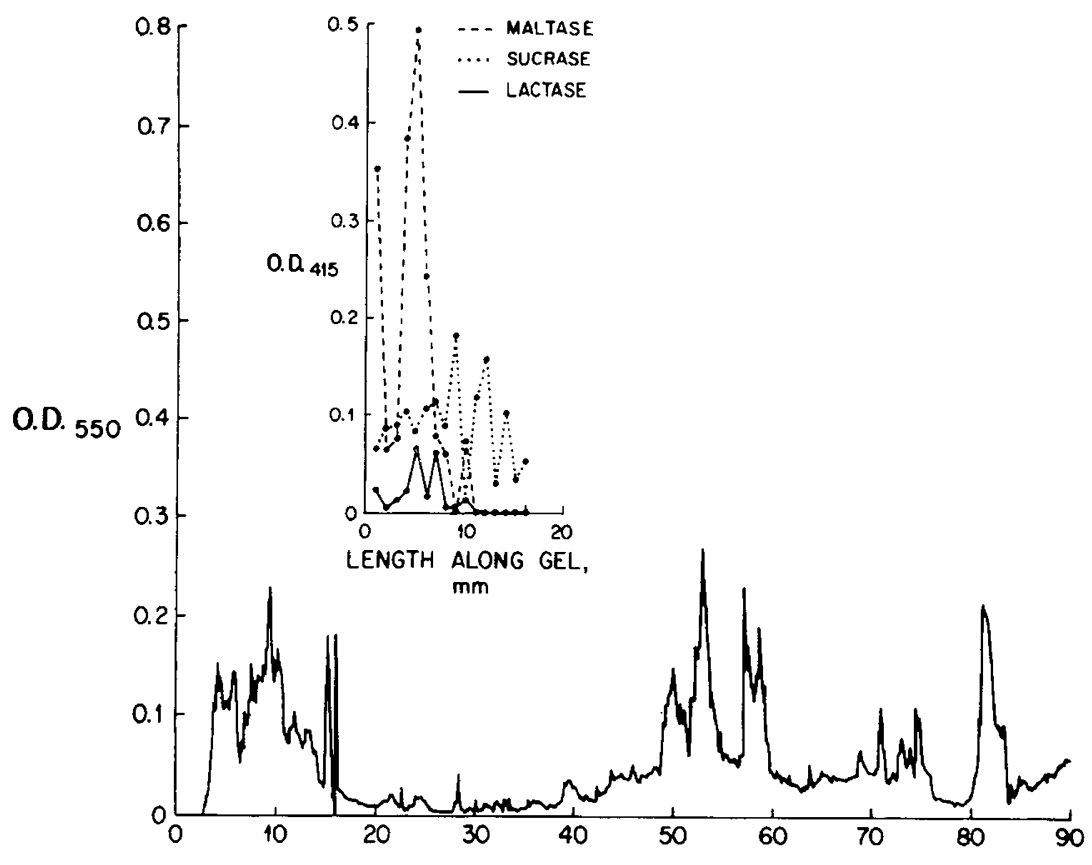

LENGTH ALONG GEL, $\mathrm{mm}$

Fig. 2. Gel scans of intestinal homogenates run on SDS-polyacrylamide disc gels with corresponding enzymatic activities of eluates from gel slices shown on inset graphs. Composite of 10 newborn pups born to ISM. The amounts of the gel eluates for each enzyme are one-third those employed in the study shown in Figure 1. Protein load, $1.0 \mathrm{mg}$.

IDD. Four were sacrificed at 21 days (Group V) and three were given iron at 21 days, placed on an ISD and sacrificed at 28 days (Group VI). The control group, born to ISM, nursed by ISM and maintained on ISD consisted of 10 animals. Table 3 shows that hemoglobin, serum iron and intestinal lactase levels in the rats born to ISM but nursed by.IDM were significantly below control levels. Following an ISD for 7 days and IM iron, the hemoglobin, serum iron, sucrase and maltase levels returned to control levels. In keeping with Study II, lactase did not respond as rapidly to correction of iron deficiency as did the other enzymes.

Study IV: Effect of iron deficiency during the postweaning period on hemoglobin, serum iron and disaccharidase levels in rats 84 days 
Table 2. Effect of maternal iron deficiency and iron deficiency during the nursing period on hemoglobin, serum iron and jejunal dissacharidase levels in rats 21 days of age and the effct of iron administration

\begin{tabular}{|c|c|c|c|c|c|c|}
\hline & & $\begin{array}{l}\mathrm{Hgb} \\
(\mathrm{g} / \mathrm{dl})\end{array}$ & $\begin{array}{c}\text { Iron } \\
(\mu \mathrm{g} / \mathrm{dl})\end{array}$ & $\begin{array}{c}\text { Sucrase } \\
(\mathrm{U} / \mathrm{g})\end{array}$ & $\begin{array}{c}\text { Lactase } \\
(\mathrm{U} / \mathrm{g})\end{array}$ & $\begin{array}{c}\text { Maltase } \\
(\mathrm{U} / \mathrm{g})\end{array}$ \\
\hline \multicolumn{7}{|c|}{ Rats sacrificed day 21 (born to IDM) } \\
\hline \multicolumn{7}{|c|}{ Group I (nursed by IDM) } \\
\hline & S.D. & \pm 0.6 & \pm 2.86 & \pm 0.09 & \pm 1.21 & \pm 0.75 \\
\hline & $2 P$ & $<0.001$ & $<0.001$ & $<0.1$ & $<0.03$ & $<0.01$ \\
\hline \multicolumn{7}{|c|}{ Group II (nursed by ISM) } \\
\hline & $2 P$ & $<0.1$ & NS & NS & $<0.001$ & $<0.005$ \\
\hline \multicolumn{7}{|l|}{ Controls ${ }^{1}$} \\
\hline & Mean & 9.8 & 93.40 & 1.30 & 5.68 & 7.22 \\
\hline & S.D. & \pm 0.8 & \pm 4.72 & \pm 0.86 & \pm 1.87 & \pm 1.57 \\
\hline \multicolumn{7}{|c|}{ Rats sacrificed day 28 after IM iron dextran on day 21 (born to IDM) } \\
\hline \multicolumn{7}{|c|}{ Group IV (nursed by ISM) } \\
\hline & Mean & 13.9 & 93.60 & 1.80 & 1.78 & 30.8 \\
\hline & S.D. & \pm 0.7 & \pm 6.46 & \pm 1.00 & \pm 0.35 & \pm 14.7 \\
\hline & $2 P$ & NS & NS & NS & $<0.1$ & NS \\
\hline \multicolumn{7}{|l|}{ Controls ${ }^{1}$} \\
\hline & Mean & 12.8 & 97.40 & 1.76 & 6.22 & 17.20 \\
\hline & S.D. & \pm 0.5 & \pm 3.90 & \pm 0.80 & \pm 2.15 & \pm 2.14 \\
\hline
\end{tabular}

${ }^{1}$ Rats born to and nursed on ISM.

Table 3. Effect of iron deficiency during the nursing period on hemoglobin, serum iron and jejunal disaccharidase levels in rats 21 days of age born to iron sufficient mothers and the effect of iron therapy

\begin{tabular}{|c|c|c|c|c|c|c|}
\hline & & $\begin{array}{l}\mathrm{Hgb} \\
(\mathrm{g} / \mathrm{dl})\end{array}$ & $\begin{array}{l}\text { Iron } \\
(\mu \mathrm{g} / \mathrm{dl})\end{array}$ & $\begin{array}{c}\text { Sucrase } \\
(\mathrm{U} / \mathrm{g})\end{array}$ & $\begin{array}{l}\text { Lactase } \\
(\mathrm{U} / \mathrm{g})\end{array}$ & $\begin{array}{c}\text { Maltase } \\
(\mathrm{U} / \mathrm{g})\end{array}$ \\
\hline \multicolumn{7}{|c|}{ Rats sacrificed day 21 (born to ISM) } \\
\hline \multirow[t]{2}{*}{ Group V (nursed by IDM) } & Mean & 5.1 & 53.0 & 2.46 & 0.52 & 10.25 \\
\hline & $2 P$ & $<0.01$ & $<0.001$ & NS . & $<0.001$ & NS \\
\hline \multirow[t]{2}{*}{ Control' $^{1}$} & Mean & 9.8 & 93.4 & 1.30 & 5.68 & 7.22 \\
\hline & S.D. & \pm 0.8 & \pm 4.7 & \pm 0.86 & \pm 1.87 & \pm 1.57 \\
\hline \multirow[t]{3}{*}{ Group VI (nursed by IDM) } & Mean & 13.3 & 91.6 & 1.00 & 0.72 & 12.23 \\
\hline & S.D. & \pm 0.3 & \pm 5.0 & \pm 0.80 & \pm 0.37 & \pm 2.87 \\
\hline & $2 P$ & NS & NS & NS & $<0.005$ & NS \\
\hline \multirow[t]{2}{*}{ Control $^{1}$} & Mean & 12.8 & 97.4 & 1.76 & 6.22 & 17.20 \\
\hline & S.D. & \pm 0.5 & \pm 3.9 & \pm 0.80 & \pm 2.15 & \pm 2.14 \\
\hline
\end{tabular}

' Rats born to ISM; nursed by ISM; and maintained on ISD.

of age born to and nursed by iron sufficient mothers and the effect of iron administration. In order to establish a model that might most closely approach the situation in man, a final investigation was conducted. Seventeen pups born to ISM were nursed by their mothers and at day 21 placed on an IDD. On day 83 lactose tolerance tests were performed on 8 animals (Group VII) and matched controls. The animals were sacrificed the following day. The remaining nine rats were given iron dextran, placed on an ISD, and on day 91 subjected to lactose tolerance testing (Group VIII) as were a comparable control group. The experiment was terminated the following day.

The data in Tables 4 and 5 show that anemia due to iron deprivation in the postweaning period was accompanied by a highly significant reduction in disaccharidases and an abnormal lactose tolerance test (Fig. 3 and 4). Iron supplementation rapidly improved all parameters.

\section{DISCUSSION}

Investigation into disaccharidase activity in iron deficiency is scant. Early studies $(3,5)$ indicated that chronic nutritional iron deficiency results in reduced sucrase, lactase and maltase activities in postweaning growing pups. Sriratanaban and Thayer (14) reported that during the postweaning period, iron deficient rats had lower disaccharidase activities. They concluded that disaccharidase deficiency in iron deficient rats was not due to protein calorie malnutrition but was due to iron deficiency per se.

The results of our study demonstrate that rats, made iron deficient in utero and during the nursing and postweaning periods, have decreased jejunal disaccharidase activities. After the rats were treated with iron the lactase activity during the nursing period remained decreased whereas reduced sucrase and maltase activities returned to normal values. During the postweaning 
Table 4. Effects of iron deficiency during post weaning period (21-84 days) on hemoglobin, serum iron and disaccharidase levels in rats 84 days of age born to and nursed by iron sufficient mothers and the effect of iron administration

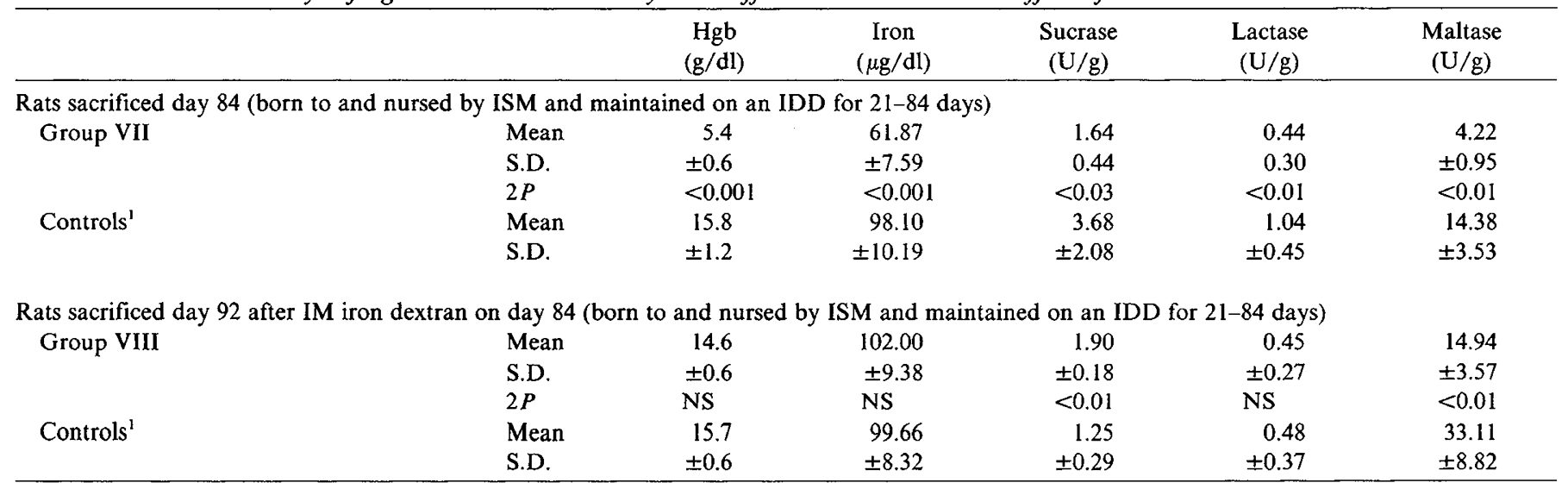

\footnotetext{
${ }^{1}$ Rats born to ISM; nursed by ISM; and maintained on ISD.
}

Table 5. Lactose tolerance tests in iron deficient rats (IDR) before and after iron treatment

\begin{tabular}{llccccc}
\hline & & \multicolumn{5}{c}{$\begin{array}{c}\text { Blood glucose level } \\
(\mathrm{mg} / \mathrm{dl})\end{array}$} \\
\cline { 3 - 7 } & & $0 \mathrm{~min}$ & $15 \mathrm{~min}$ & $30 \mathrm{~min}$ & $45 \mathrm{~min}$ & $60 \mathrm{~min}$ \\
\hline Before (group VIII) & & & & & \\
IDR & Mean & 88.13 & 133.00 & 149.50 & 140.60 & 140.37 \\
& S.D. & \pm 13.41 & \pm 19.60 & \pm 21.24 & \pm 10.66 & \pm 9.07 \\
Controls & Mean & 80.09 & 152.13 & 175.38 & 192.25 & 177.38 \\
& S.D. & \pm 7.91 & \pm 20.53 & \pm 19.57 & \pm 5.89 & \pm 5.80 \\
& 2P & NS & NS & $<0.05$ & $<0.001$ & $<0.001$ \\
After (group IX) & & & & & & \\
IDR & Mean & 79.10 & 143.40 & 163.1 & 183.00 & 179.90 \\
& S.D. & \pm 7.20 & \pm 8.30 & \pm 8.8 & \pm 7.90 & \pm 8.10 \\
Controls & Mean & 80.6 & 147.50 & 168.70 & 188.50 & 171.50 \\
& S.D. & \pm 6.4 & \pm 9.90 & \pm 8.50 & \pm 7.20 & \pm 7.20 \\
& 2P & NS & NS & NS & NS & NS \\
\hline
\end{tabular}

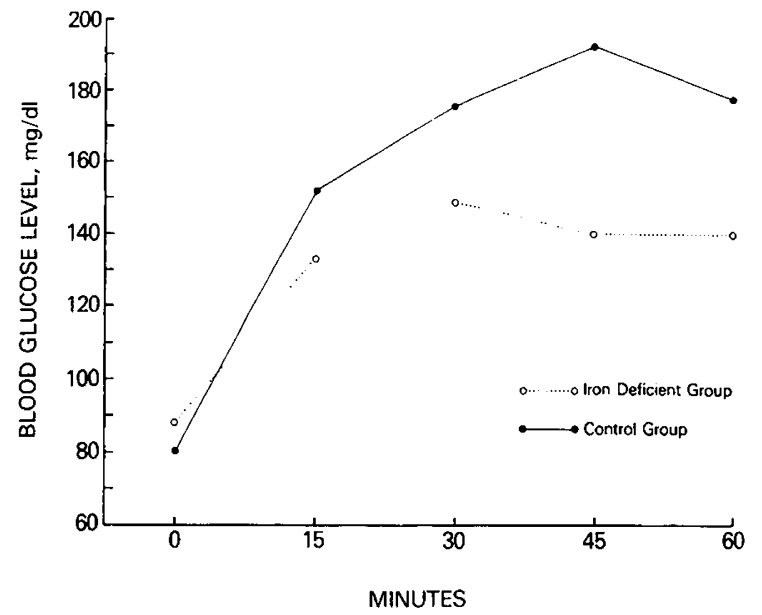

Fig. 3. Lactose tolerance curves in iron deficient rats and controls before iron treatment.

period (at 91 days of age) lactase activity returned to normal whereas sucrase and maltase remained decreased. This varying response to iron treatment in certain disaccharidases in different stages of development are probably very much related to the postnatal development of various digestive and absorptive functions of the small intestine. In the rat, it has been shown (1) that

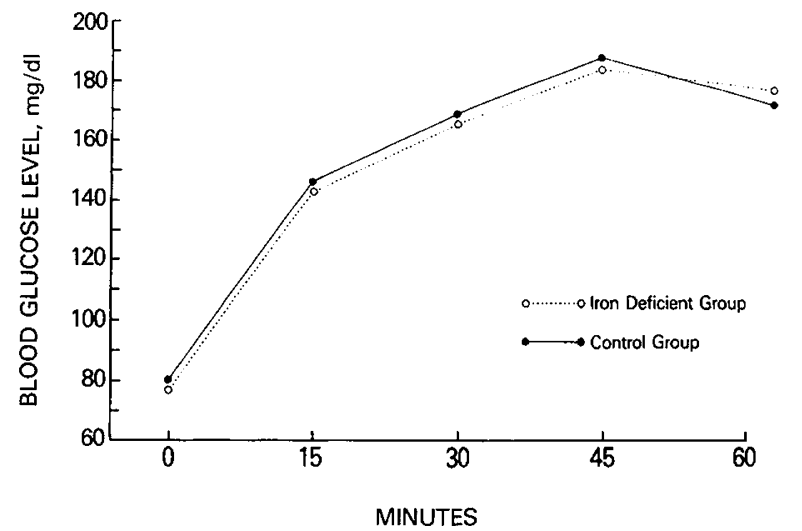

Fig. 4. Lactose tolerance curves in iron deficient rats and controls after iron treatment.

lactase is detectable on the eighteenth day of gestation, has maximal activity during the first wk after birth, and then begins to decline, reaching adult values by the end of the fourth wk. Sucrase and maltase, however, are very low in the intestinal mucosa of suckling rats and then rise suddenly during the third wk, reaching adult values by the end of weaning $(11,12)$. Our study also revealed that protein concentration is roughly related to enzyme activity on the brush border membrane and that the entire protein profile is altered by iron deprivation. We integrated the enzyme activity and the corresponding protein absorption along the gel. The ratios were variable but sufficient to say that iron deficiency leads to altered enzyme profiles and decreased total activity. Iron deficiency appears to alter the entire protein synthetic mechanism or at least a significant component thereof.

In conclusion, iron deficiency in rats results in reduction of jejunal disaccharidase activities probably by altering the enzyme in the brush border membrane. Varying degrees of reduction of disaccharidase and response to iron treatment of certain disaccharidases are related to the timing of iron deprivation during the postnatal development of digestive and absorptive functions of the small intestine. It should be emphasized that iron deficiency has a profound effect on protein synthesis, not necessarily related to iron content (15). The alterations in the levels of disaccharidases represent only a fraction of this effect. The significance of lactase deficiency is probably due to the fact that it is present in low amounts. Decreased synthesis of this enzyme results in a critical lack whereas both sucrase and maltase have much greater reserves. The importance of diminished activity is of course dependent on the age of the animal and its diet.

The significance of these findings with reference to human iron 
deficiency may be very important. The temporary reduction in lactase and other disaccharidases in iron-deficient infants may predispose them to malabsorption of sugar with subsequent diarrhea, which contributes to the lower serum proteins and increased incidence of lower weight percentiles that have been observed in iron-deficient infants $(4,6,7)$.

\section{REFERENCES AND NOTES}

1. Doell, R. G. and Kretchmer, N.: Studies of the small intestine during development I. distribution and activity of $\beta$-galactosidase. Biochem. Biophys. Acta., 62: 353 (1962).

2. Freiburghaus, A. U., Hauri, H. P., Green, J., and Hadorn, B.: A micro-method for separation and identification of digestive enzymes in brush border membrane fragments of single human intestinal biopsies. Clin. Chim. Acta., 86: 227 (1978).

3. Hoffbrand, A. V. and Broitman, S. A.: Effect of chronic nutritional iron deficiency on the small intestinal disaccharidase activities of growing dogs. Proc. Soc. Exptl. Biol. Med., 130: 595 (1969).

4. Judisch, J. M., Naiman, J. L., and Oski, F. A.: The fallacy of the fat iron deficient child. Pediatrics, 37: 987 (1966)

5. Kimber, C. and Weintraub, L. R.: Malabsorption of iron secondary to iron deficiency. N. Engl. J. Med., 279: 453 (1968).

6. Lanzkowsky, P.: Iron Deficiency Anemia: A Public Health Problem. Monograph. Mead Johnson Labs, Evansville, Indiana, 1975.

7. Lanzkowsky, P.: Iron metabolism and iron deficiency anemia. In: Denis R. Miller and Howard A. Pearson, Eds.: Smith's Blood Diseases of Infancy and Childhood. Fourth Ed., pp. 108-172. (C. V. Mosby, St. Louis, MO, 1978).

8. Lowry, O. H., Rosebrough, N. J., Farr, A. L., and Randall, R. J. J.: Protein measurement with the folin reagent. Biol. Chem., 193: 265 (1951).

9. Pennock, C. A., Murphy, D., Sellers, J., and Longdon, K. J.: A comparison of autoanalyzer methods for the estimation of glucose in blood. Clin. Chim. Acta., 48: 193 (1973).

10. Peters, T. J., Batt, R. M., Heath, J. R., and Tilieray, K.: The microassay of intestinal disaccharidases. Biochem. Med., 15: 145: (1976).

11. Reddy, B. S. and Wostmann, B. S.: Intestinal disaccharidase activities in growing germfree and conventional rats. Arch. Biochim. Biophys., 113: 609 (1966)

12. Rubino, A., Zimbalatti, R., and Auricchio, S.: Intestinal disaccharidase activity in adult and suckling rats. Biochem. Biophys. Acta., 92: 305 (1964).

13. Seetharam, B., Yeh, K. Y., Moog, F., and Alpers, D. H.: Development of intestinal brush border membrane proteins in the rat. Biochem. Biophys. Acta., 470: 424 (1977)

14. Sriratanaban, A. and Thayer, W. R., Jr.: Small intestinal disaccharidase activities in experimental iron and protein deficiency. Am. J. Clin. nutr., 24: 411 (1971).

15. Srivastava, S. K Sanwal, G. G and Tewari, K. K. Biochemical alterations in rat tissue in iron deficiency anaemia and repletion with iron. Indian $J$. Biochem., 2: 257 (1965).

16. The authors thank Mr. Abdul Basir for his assistance in the preparation of the animals and Ms. Gale Dutcher, Mr. Joseph Pastore and Mr. Robert Skinner for excellent technical assistance in conducting the enzymatic and disc gel electrophoretic analyses.

17. Requests for reprints should be addressed to: Dr. Philip Lanzkowsky, Department of Pediatrics, Long Island Jewish-Hillside Medical Center, New Hyde Park, New York 11042

18. This research was supported by a Long Island Jewish-Hillside Medical Center Research Grant No. 3-792 and in part by a grant from the National Cancer Institute, $\mathrm{CA}$

19. Received for publication September $26,1980$.

20. Accepted for publication August 20, 1981. 